\title{
Analisis Strategi Pemasaran dengan Menggunakan Metode SWOT Guna Peningkatan Penjualan Produk Lemari di UD Abdi Rakyat
}

\author{
Muhammad Rizky Surya Aistiawan ${ }^{1}$, Deny Andesta ${ }^{2}$ \\ 1,2Program Studi Teknik Industri, Fakultas Teknik, Universitas Muhammadiyah Gresik \\ Jl. Sumatera No.101, Randuagung, Kec. Kebomas, Kabupaten Gresik, Jawa Timur 61121 \\ *Koresponden email: samuelrizky21@gmail.com, deny_andesta@umg.ac.id
}

Diterima : 10 Desember 2021

Disetujui : 8 Januari 2021

\begin{abstract}
UD Abdi Rakyat is a business engaged in the manufacture of cabinet products with the ingredients are glass and aluminum. In the process of selling products often experience conditions where the number of cabinet sales is volatile and erratic every week, characterized by an increase and decrease in unstable sales. This research uses SWOT analysis that contains strategy planning steps to evaluate all forms of strengths, weaknesses, opportunities and threats in an effort. The purpose this study to find the factors that cause fluctuating sales and know the marketing strategies to be used in efforts to increase sales of their products. The results of this study show that there are various internal-external factors that hinder the course of the business. The total score value of the IFAS\&EFAS matrix calculations is Strength 2.86, Weakness 2.33, Opportunity 1.80 and Threat 1.70. The results the SWOT matrix diagram show that UD. Abdi Rakyat is in quadrant $I$ and has a positive weighted difference value $(0.53 ; 0.10)$. From the various kinds of formation strategies to increase sales of cabinet products, it was concluded that the business needed to apply the SO strategy so that the company's goals could be achieved quickly and appropriately.
\end{abstract}

Keywords: SWOT analysis, IFAS \& EFAS Matrix, IE Matrix, cabinet product, marketing strategy

\begin{abstract}
Abstrak
UD. Abdi Rakyat merupakan usaha di bidang pembuatan lemari dengan bahan utamanya kaca dan aluminium. Penjualan produknya sering mengalami kondisi fluktuatif, ditandai dengan peningkatan dan penurunan penjualan yang tidak stabil Penelitian ini menerapkan analisis metode SWOT yang berisi langkah perencanaan strategi untuk mengevaluasi segala bentuk kekuatan, kelemahan, peluang dan ancaman dalam setiap usaha. Tujuan penelitian ini adalah mengetahui faktor penyebab penjualan lemari yang fluktuatif dan mengetahui strategi pemasaran yang cocok digunakan dalam usaha peningkatan penjualan produknya. Hasil penelitian menunjukkan terdapat berbagai macam faktor internal-eksternal yang menghambat jalannya usaha tersebut. Nilai total skor dari perhitungan matriks IFAS\&EFAS yaitu Strength 2,86, Weakness 2,33 , Opportunity 1,80 dan Threat 1,70. Hasil diagram matriks SWOT menunjukkan bahwa UD. Abdi Rakyat berada pada kuadran I dan memiliki nilai selisih tertimbangnya positif yakni $(0,53 ; 0,10)$. Dari berbagai banyak macam pembentukan strategi peningkatan penjualan produk lemari di UD Abdi rakyat, maka disimpulkan bahwa usaha tersebut perlu mengaplikasikan strategi SO agar tujuan perusahaan dapat tercapai dengan cepat dan tepat.
\end{abstract}

Kata Kunci : analisis SWOT, Maktris IFAS \& EFAS, Matriks IE, produk lemari, strategi pemasaran

\section{Pendahuluan}

Di era perkembangan yang serba modern ini dapat mengakibatkan banyak persaingan di dunia industri, baik dari dalam maupun luar industri tersebut. Hal ini, juga terjadi karena perubahan bidang teknologi yang semakin cepat. Dengan adanya kondisi pertumbuhan teknologi yang pesat dan cepat dapat diidentifikasikan sebagai suatu kondisi yang tidak heran lagi bagi pelaku usaha, terkhusus bagi perusahaan yang beroperasi dalam bidang produksi barang, dengan kondisi tersebut maka manajemen perusahaan akan saling bertanding dalam meningkatkan proses penjualan kepada konsumen melalui berbagai media pemasaran yang ada saat ini. Pada umumnya setiap perusahaan harus memiliki upaya untuk memenuhi harapan konsumen sehingga dapat menciptakan konsumen yang komitmen untuk menggunakan produk yang ditawarkan oleh perusahaan.

Setiap perusahaan akan dituntut untuk menciptakan keunggulan bersaing, dimana dengan kondisi ketatnya persaingan di era modern saat ini secara tidak langsung dapat mempengaruhi profit perusahaan dan berdampak pada pertumbuhan suatu perusahaan. Untuk meningkatkan kondisi kompetisi antar perusahaan, maka dapat terjadi perubahan perilaku konsumen terhadap tuntutan kualitas produk, harga serta 
service yang diberikan [1]. Suatu perusahaan perlu melakukan suatu penerapan strategi yang akurat agar persaingan antar perusahaan dapat berjalan baik sehingga perusahaan tumbuh dan berkembang pesat. Perumusan strategi yang tepat butuh suara keputusan dari manajer, agar perusahaan dapat menerapkan strategi yang paling tepat dilaksanakan dan dikelola secara efektif dan efisien [2].

Saat ini strategi pemasaran sedang dalam kondisi persaingan yang semakin berkembang dalam berjalannya suatu usaha, sehingga dengan kondisi tersebut dapat mendesak perusahaan untuk bersikap kreatif dan inovatif dalam mempromosikan sesuatu yang memiliki nilai lebih dibanding kompetitor lainnya [3]. Dalam berjalannya usaha dibtuhkan penyusunan strategi pemasaran yang merupakan faktor penentu kesuksesan usaha tersebut dalam mewujudkan visi dan misinya sehingga dapat memenangkan persaingan dalam penjualan produknya. Strategi pemasaran harus dilakukan secara efektif agar dapat menjaga pangsa pasar yang dimiliki atau bisa juga memperluas jangkauan konsumen, mengetahui ke arah mana usaha tersebut berjalan dan tindakan yang harus dilakukan untuk meningkatkan kekuatan dan merebut peluang yang ada. Penerapan strategi bisa dilakukan dengan mengetahui kondisi di perusahaan dari empat faktor sekaligus, yaitu Strengths, Weaknesses, Opportunities dan Threats kekuatan dalam melakukan penjualan produknya atau bisa dikatakan menggunakan pendekatan analisis metode SWOT [4].

Metode SWOT didefinisikan sebagai metode dalam merencanakan sesuatu untuk evaluasi segala bentuk kondisi Strengths, Weaknesses, Opportunities dan Threats dalam suatu usaha di bidang manufaktur maupun jasa yang diterapkan dengan cara analisis berbagai kondisi real yang dapat memberikan pengaruh terhadap faktor tersebut [5]. Analisis metode SWOT ini penting dilakukan bagi setiap jalannya suatu usaha baik itu manufaktur atau jasa, karena untuk mempersiapkan manajemen strategi yang akan pilih dan digunakan agar perusahaan dapat bersaing dengan kompetitornya [6]. Metode SWOT (Strengths, Weaknesses, Opportunities dan Threats) menggambarkan lingkungan internal serta lingkungan eksternal yang dihadapi oleh pelaku usaha. Adapun penerapan metode SWOT ini dengan melakukan identifikasi dan evaluasi terhadap keempat faktor internal-eksternal agar dapat ditentukan strategi pemasaran yang meningkatkan penjualan produk.

Penelitian terdahulu yang telah dilakukan untuk memperkuat gagasan bahwa strategi pemasaran sangat berguna untuk pengembangan perusahaan terlebih dalam peningkatan penjualan produk, salah satunya yang dilakukan oleh [7] terkait penerapan metode SWOT untuk peningkatan penjualan produk asuransi tabungan di PT Prudential cabang Manado. Penerapan metode SWOT ini dinilai berhasil untuk mengidentifikasi strategi pemasaran yang digunakan dalam upaya peningkatan penjualannya. Hasil analisis SWOT menyatakan perusahaan tersebut memiliki strategi agresif dan dinilai bisa memperkuat posisi perusahaan jika melakukan investasi dalam menjaga produktivitas melalui teknologi dan tenaga kerja, teliti dalam kelemahan pendatang baru.

UD. Abdi Rakyat merupakan salah satu usaha dagang yang berdiri tahun 1983 dan bergerak di bidang pembuatan produk lemari dengan bahan utamanya adalah kaca dan aluminium. Usaha tersebut berada di Desa. Dukun Anyar, Kec. Dukun, Kab. Gresik. Pada awalnya, usaha ini merupakan usaha kecil yang hanya memiliki 2 karyawan, seiring berjalannya waktu UD. Abdi Rakyat telah berkembang dan dapat bersaing dengan kompetitor lainnya khususnya di Kab. Gresik. UD. Abdi rakyat selalu berada pada kondisi peningkatan penjualan produk dari tahun ke tahun dengan minimum penjualan dalam 1 minggu sebanyak 48 produk. Saat ini, UD. Abdi Rakyat memiliki 8 karyawan dan beberapa mesin untuk mendukung produksi. Hasil penjualan produksi lemari di UD. Abdi Rakyat diuraikan pada Tabel 1.

Tabel 1. Data penjualan produk di UD. Abdi Rakyat periode Oktober-Desember 2020

\begin{tabular}{ccc}
\hline No. & Minggu Ke- & Banyaknya Penjualan (Pcs) \\
\hline 1 & $\mathrm{Ke}-1$ & 42 \\
2 & $\mathrm{Ke}-2$ & 38 \\
3 & $\mathrm{Ke}-3$ & 35 \\
4 & $\mathrm{Ke}-4$ & 40 \\
5 & $\mathrm{Ke}-5$ & 39 \\
6 & $\mathrm{Ke}-6$ & 39 \\
7 & $\mathrm{Ke}-7$ & 40 \\
8 & $\mathrm{Ke}-8$ & 42 \\
9 & $\mathrm{Ke}-9$ & 40 \\
10 & $\mathrm{Ke}-10$ & 39 \\
11 & $\mathrm{Ke}-11$ & 35 \\
12 & $\mathrm{Ke}-12$ & 33 \\
\hline
\end{tabular}

Sumber : UD. Abdi Rakyat (2020) 


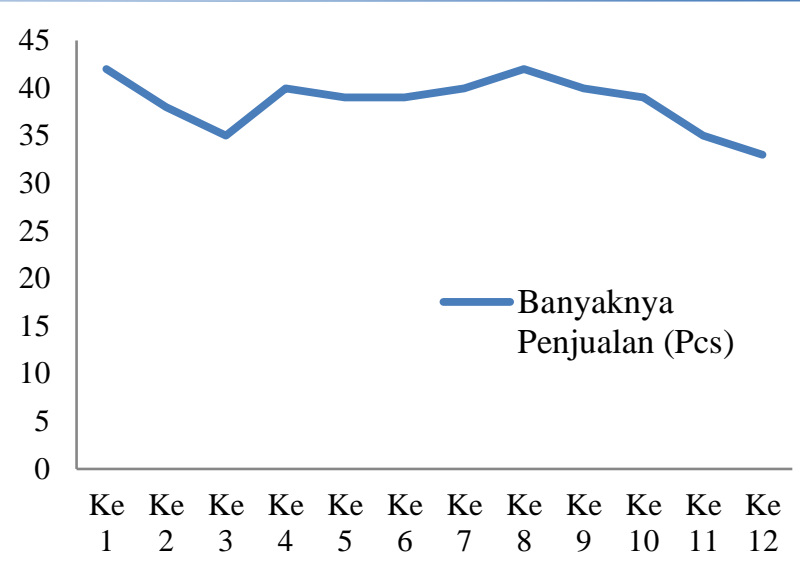

Gambar 1. Data penjualan Di UD. Abdi Rakyat Oktober - Desember 2020 Sumber : Data diolah (2020)

Data Tabel 1 dan grafik pada Gambar 1 terkait data penjualan produk lemari di UD Abdi Rakyat periode Oktober - Desember 2020, dapat disimpulkan bahwa jumlah penjualan lemari bersifat fluktuatif dan tidak menentu setiap minggunya, dimana terjadi peningkatan dan penurunan penjualan produk lemari mulai periode minggu ke -1 hingga minggu ke- 8 , sedangkan laju penurunan penjualan lemari terjadi dimulai periode minggu ke-9 hingga minggu ke -12 .

Dengan kondisi saat ini, dimana UD Abdi Rakyat menghadapi volume penjualan yang fluktuatif, maka diperlukan suatu perencanaan strategi pemasaran yang tepat menggunakan metode SWOT yang memperhatikan semua faktor internal lingkungan dan eksternal usaha sehingga dapat meningkatkan penjualan produk lemari di UD Abdi Rakyat. Analisis SWOT (Strengths, Weaknesses, Opportunities dan Threats) yang diterapkan dipenelitian ini dilaksanakan secara internal dan eksternal perusahaan. Adapun untuk mengetahui berbagai hal yang termasuk ke dalam kekuatan dan kelemahan dari usaha lemari UD. Abdi Rakyat dilakukan suatu analisis internal, sedangkan untuk mengetahui peluang yang dapat diambil dan ancaman yang mampu dihadapi oleh usaha tersebut dilakukan analisis eksternal.

Berdasarkan permasalahan yang ada di UD. Abdi Rakyat dalam peningkatan penjualan produk lemari, maka dibutuhkan suatu pelaksanaan penelitian yang bertujuan mengetahui akar permasalahan atau kondisi yang menyebabkan penjualan menurun dan mengetahui strategi pemasaran seperti apa yang cocok digunakan di UD. Abdi Rakyat dalam upaya peningkatan penjualan produknya. Adapun hasil analisis pada penelitian ini bisa digunakan pemilik dan karyawan di UD. Abdi Rakyat sebagai petunjuk dan evaluasi bagi pemilik usaha tersebut untuk selalu meng-upgrade strategi pemasaran yang digunakan dalam proses penjualan produk lemari.

\section{Metode Penelitian}

Pelaksanaan penelitian ini menggunakan pendekatan kuantitatif dan deskriptif untuk memperoleh informasi lebih terkait faktor internal dan eksternal perusahaan. Penelitian ini fokus menggambarkan strategi peningkatan penjualan produk lemari di UD. Abdi Rakyat. Analisis SWOT digunakan dalam proses mengidentifikasi berbagai faktor eksternal dan internal, rating factor, perumusan strategi dan penentuan strategi pemasaran produk lemari di UD. Abdi Rakyat untuk meningkatkan penjualan. Adapun penelitian ini terdiri dari data primer dan data sekunder. Data primer didapatkan melalui tahapan interview dan penyebaran kuesioner kepada pemilik dan karyawan di UD. Abdi Rakyat. Data sekunder didapatkan dengan cara studi literatur.

Metodologi penelitian berisi suatu prosedur yang akan dilakukan dalam sebuah penelitian untuk membantu memecahkan permasalahan yang ada sehingga ditemukan solusi yang terbaik. Adapun langkah yang digunakan untuk penyelesaian masalah di UD Abdi Rakyat dengan analisis metode SWOT ditunjukkan pada Gambar 2. 


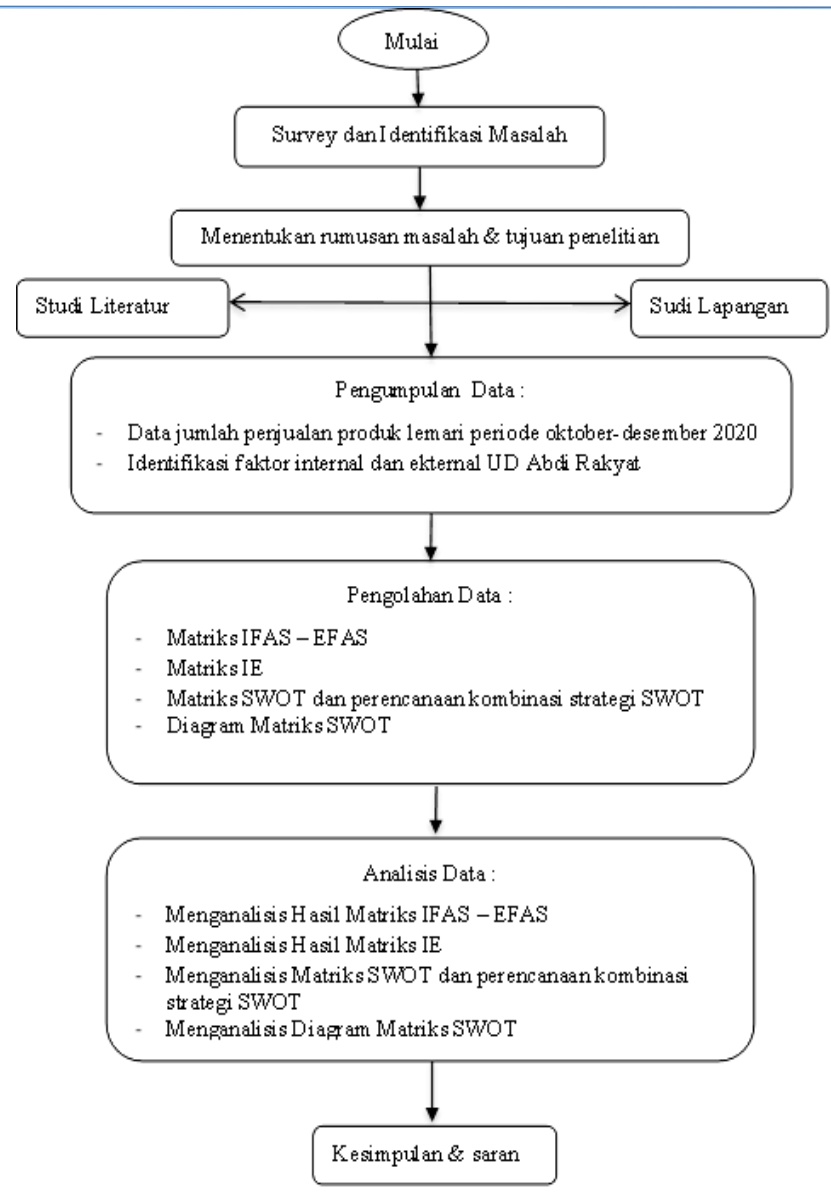

Gambar 2. Metode Penelitian

Sumber: Data peneliti (2020)

\section{Strategi Pemasaran}

Strategi pemasaran merupakan usaha terintegrasi untuk mencapai keuntungan kompetitif yang berkelanjutan mulai dari formulating, implementing dan evaluating program pemasaran terhadap permintaan produknya [8]. Adapun inti dari strategi pemasaran modern terdiri atas STP (Segmenting, Targeting, Positioning) [3]. Secara umum, terdapat jenis strategi pemasaran bagi setiap pelaku usaha, yaitu [2] : Strategi pemasaran tidak membedakan pangsa pasarnya, Strategi pemasaran yang membedakan pangsa pasarnya dan Strategi pemasaran yang terkonsentrasi.

\section{Matriks IFAS \& EFAS}

Matriks IFAS\&EFAS digunakan untuk menganalisis berbagai faktor internal dan eksternal yang mempengaruhi keberlangsungan suatu perusahaan [6]. Adapun penilaian matriks IFAS melakukan pembobotan kekuatan dan kelemahan dalam jalannya setiap perusahaan dari segi internal [5]. Adapun penilaian matriks EFAS melakukan pembobotan peluang dan ancaman dalam jalannya suatu usaha dari segi eksternal [5]. Menurut [9], adapun tahapan dalam analisis IFAS \& EFAS yaitu pengumpulan data faktor-faktor yang ada, pemberian bobot yang tidak boleh lebih dari 1, pemberian rating, perkalian bobot, penjumlahan skor dan analisis keseluruhan faktor internal dan eksternal yang ada. Penggambaran matriks ini berdasarkan data sumbu $\mathrm{X}$ dan $\mathrm{Y}$, adapun untuk sumbu $\mathrm{X}$ menggunakan nilai total pembobotan IFAS dan untuk sumbu Y menggunakan nilai total pembobotan EFAS, hal itu dilakukan agar strategi bisnis yang digunakan berada di kondisi yang lebih baik [11].

\section{Matriks Internal-Eksternal (IE)}

Matriks IE melakukan penggambaran kondisi berbagai faktor internal-eksternal perusahaan yang bertujuan mendapatkan strategi bisnis pada kondisi yang akan digapai sehingga perumusan alternatif strategi bisa sesuai [10]. Penggambaran Matriks Internal-eksternal memiliki ketentuan strategis yang berbeda-beda, sebagai berikut [11], [12] : Sel I, II, IV cocok dengan penerapan strategi yang intensif dan integrasi. Sel III, V, VII cocok dengan penerapan strategi penetrasi pasar dan pengembangan produk. Sel VI, VIII, IX cocok dengan penerapan strategi divestasi, diversifikasi dan likuidasi. 


\section{Analisis SWOT}

Penerapan analisis SWOT untuk merencanakan strategis yang sesuai dengan kondisi perusahaan yang bertujuan mengevaluasi segala bentuk kondisi real dalam suatu bisnis yang dijalankan. Analisis SWOT juga melakukan suatu intergasi Strengths Weaknesses yang dimiliki untuk disesuaikan dengan Opportunities dan Threats di suatu perusahaan [13], [14]. Terdapat manfaat dan kelebihan penerapan analisis SWOT, anatara lain [15] : mampu memandang kondisi perusahaan dari empat sisi (Strengths, Weaknesses, Opportunities dan Threats ), dapat memberikan hasil dalam bentuk analisis yang cukup tajam, serta dapat digunakan sebagai instrumen analisa strategi untuk mendapatkan suatu langkah terbaik sesuai kondisi real di tiap perusahaan.

\section{Matriks SWOT}

Penggambaran matriks SWOT melakukan suatu perumusan strategi dengan kombinasi empat faktor sekaligus sehingga mampu mendapatkan empat elemen strategi yaitu SO, WO, ST dan WT [16]. Adapun menurut ref. [12] mendefinisikan keempat elemen strategi sebagai berikut : Strategi SO ini memakai kekuatan perusahaan untuk memanfaatkan peluang. Strategi WO memanfaatkan peluang untuk meminimalkan kelemahan. Strategi ST memanfaatkan kekuatan untuk mengatasi ancaman. Strategi meminimalkan kelemahan dan menghindari ancaman eksternal.

\section{Diagram matriks SWOT}

Diagram matriks SWOT menggambarkan alternatif strategi yang harus diambil oleh suatu jenis usaha agar terarah untuk menggunakan segala kondisi yang ada di perusahaan [2]. Dari hasil matriks SWOT akan diperoleh empat kelompok alternatif strategi SO,WO, ST dan WT. Adapun penilaian situasi diagram matriks SWOT sebagai berikut [5] : Kuadran I mewujudkan kondisi menguntungkan. Kuadran II mewujudkan situasi yang menghadapi berbagai ancaman. Kuadran III mewujudkan situasi menghadapi peluang yang besar. Kuadran IV mewujudkan situasi yang menimbulkan kerugian yang besar.

\section{Hasil dan Pembahasan}

Pengumpulan data yang digunakan pada penelitian ini berupa data historis penjualan produk lemari periode Oktober sampai Desember 2020 di UD Abdi Rakyat serta melakukan proses wawancara, penyebaran kuesioner dan brainstorming ke pemilik usaha untuk mendapatkan data faktor internaleksternal perusahaan yang menghambat proses penjualan produknya. Penyebaran kuesioner dilakukan terhadap pekerja di UD Abdi Rakyat yang berjumlah 8 orang dan 1 orang owner. Hasil aplikasi metode analisis SWOT tersebut dapat mengetahui kondisi yang ada di usaha tersebut dari empat faktor sekaligus.

\section{Faktor eksternal internal}

Adapun terdapat data faktor internal-eksternal yang berhasil dikumpulkan oleh peneliti dengan wawancara dan penyebaran kuesioner mengenai kondisi penjualan produk lemari di UD Abdi Rakyat menggunakan analisis SWOT yang diuraikan pada Tabel 2.

Tabel 2. Faktor Internal Eksternal UD. Abdi Rakyat

\begin{tabular}{ll}
\hline \multicolumn{1}{c}{ Strength $(S)$} & \multicolumn{1}{c}{ Weakness $(W)$} \\
1. Kualitas produk bagus & 1. Kondisi keuangan terbatas \\
2. Pekerjaan cepat dan akurat & 2. Promosi tidak efisien \\
3. Bahan baku mudah diperoleh & 3. Bentuk produk kurang bervariasi \\
4. Pelayanan baik & 4. Kualitas SDM yang terbatas \\
5. Citra baik di masyarakat & \multicolumn{1}{c}{ Opportunities $(O)$} \\
\hline $\begin{array}{l}\text { 1. Pelanggan loyal } \\
\text { 2. Produk bisa digunakan semua }\end{array}$ & 1. Tingkat persaingan tinggi \\
kalangan & 2. Fluktuasi harga bahan baku \\
3. Harga menengah ke bawah & 3. Permainan harga dari kompetitor \\
& 4. Kompetitor mulai meniru produk yang diproduksi \\
\hline
\end{tabular}

Sumber: Hasil wawancara (2021)

Berdasarkan data Tabel 2, diketahui data faktor internal-eksternal penjualan produk lemari di UD. Abdi Rakyat. Adapun untuk faktor kekuatan (Strengths) di penelitian ini melambangkan potensi yang telah dimiliki oleh usaha tersebut untuk dilakukan peningkatan penjualan di periode yang akan datang. Sedangkan faktor kelemahan (Weakness) di penelitian ini adalah hambatan yang muncul dalam proses peningkatan penjualan di usaha tersebut. Adapun untuk faktor peluang (Opportunities) di penelitian ini adalah situasi yang merupakan peluang diluar dari jalannya usaha tersebut dan memberikan dampak positif perkembangan produk untuk periode ke depan. Sedangkan faktor ancaman (Threats) dipenelitian ini adalah 
kondisi tantangan yang muncul dan harus dihadapi dengan tepat dan bersifat merugikan serta bisa menjadi penghalang usaha tersebut untuk melakukan peningkatan penjualan produk periode ke depan.

\section{Matriks IFAS \& EFAS}

Setelah kondisi internal dan eksternal di UD. Abdi Rakyat di identifikasi, maka langkah selanjutnya di susun suatu matriks IFAS \& EFAS untuk merumuskan faktor-faktor strategi internal-eksternal yang kemudian akan dilakukan perhitungan nilai bobot, rating dan skornya. Adapun nilai bobot dan rating yang ada di matriks IFAS \& EFAS diperoleh dengan cara rata-rata hasil penyebaran kuesioner terhadap obyek penelitian yang sudah ditentukan sebelumnya oleh penulis. Sedangkan hasil skor diperoleh dengan cara perkalian antara nilai bobot dan rating faktor.

Penilaian bobot faktor dimulai dari angka 0,0 sampai angka1,0 dan jumlah keseluruhan bobot faktor sama dengan satu. Sedangkan pengisian rating faktor yaitu untuk nilai 1 (tidak signifikan), 2 (kurang signifikan), 3 (signifikan) dan 4 (sangat signifikan) Adapun perhitungan untuk matriks IFAS dapat dilihat pada Tabel 3.

Tabel 3. Internal Factors Analysis Summary (IFAS)

\begin{tabular}{|c|c|c|c|c|}
\hline No. & Faktor strategi Internal & Bobot & Rating & Skor \\
\hline \multicolumn{5}{|c|}{ Kekuatan } \\
\hline 1. & Kualitas produk bagus & 0,25 & 4 & 1,00 \\
\hline 2. & Pekerjaan cepat dan akurat & 0,15 & 3 & 0.45 \\
\hline 3. & Bahan baku mudah diperoleh & 0,15 & 3 & 0,45 \\
\hline 4. & Pelayanan baik & 0,12 & 3 & 0,36 \\
\hline 5. & Citra baik di masyarakat & 0,15 & 4 & 0,6 \\
\hline \multirow{2}{*}{\multicolumn{5}{|c|}{$\begin{array}{l}\text { Sub Total } \\
\text { Kelemahan }\end{array}$}} \\
\hline & & & & \\
\hline 1. & Kondisi keuangan terbatas & 0,15 & 4 & 0,60 \\
\hline 2. & Promosi tidak efisien & 0,15 & 3 & 0,45 \\
\hline 3. & Bentuk produk kurang bervariasi & 0,20 & 4 & 0,80 \\
\hline 4. & Kualitas SDM yang terbatas & 0,12 & 4 & 0,48 \\
\hline \multicolumn{2}{|r|}{ Sub Total } & 0,62 & 15 & 2,33 \\
\hline
\end{tabular}

Sumber : Hasil kuesioner (2021)

Pada Tabel 3, menunjukkan hasil penilaian faktor internal proses penjualan lemari di UD. Abdi Rakyat. Dari hasil analisis mengenai strategi faktor internal (IFAS) menunjukkan bahwa faktor kekuatan memiliki total nilai skor 2,86 sedangkan kelemahan memiliki total nilai skor 2,33. Adapun perhitungan untuk matriks EFAS dapat dilihat pada Tabel 4.

Tabel 4. Eksternal Factors Analysis Summary (EFAS)

\begin{tabular}{|c|c|c|c|c|}
\hline No. & Faktor - faktor strategi Eksternal & Bobot & Rating & Skor \\
\hline \multicolumn{5}{|c|}{ Peluang } \\
\hline 1. & Pelanggan loyal & 0,20 & 3 & 0,60 \\
\hline 2. & Produk bisa digunakan untuk semua kalangan & 0,20 & 3 & 0,60 \\
\hline 3. & Harga menengah ke bawah & 0,15 & 4 & 0,60 \\
\hline & Sub Total & 0,55 & 10 & 1,80 \\
\hline \multicolumn{5}{|c|}{ Ancaman } \\
\hline 1. & Tingkat persaingan tinggi & 0,10 & 3 & 0,30 \\
\hline 2. & Fluktuasi harga bahan baku & 0,10 & 3 & 0,30 \\
\hline 3. & Permainan harga dari kompetitor & 0,10 & 3 & 0,40 \\
\hline 4. & Kompetitor mulai meniru produk yang diproduksi & 0,15 & 4 & 0,60 \\
\hline 5. & Tingkat Inflasi yang meningkat & 0,05 & 2 & 0,10 \\
\hline \multicolumn{2}{|r|}{ Sub Total } & 0,50 & 15 & 1,70 \\
\hline
\end{tabular}

Data pada Tabel 4, menunjukkan hasil penilaian faktor eksternal dalam proses penjualan lemari di UD. Abdi Rakyat. Dari hasil analisis terkait bobot strategi EFAS, faktor Opportunity dengan total skor 1,80, sedangkan untuk Threat dengan total skor 1,70. Kemudian total nilai skor empat faktor diuraikan sebagai berikut : Strength 2,86, Weakness 2,33, Opportunity 1,80 dan Threat 1,70.

\section{Matriks SWOT}

Matriks SWOT yang ada pada penelitian ini dilakukan dengan penggabungan kondisi internaleksternal UD. Abdi Rakyat guna peningkatan volume penjualan produk lemari. Hasil dari matriks SWOT 


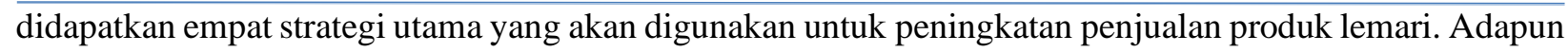
penggambaran matriks SWOT diuraikan pada Tabel 5.

Tabel 5. Matrik SWOT

1. Kualitas produk bagus

2. Pekerjaan cepat dan akurat

3. Bahan baku mudah diperoleh

4. Pelayanan baik

5. Citra baik di masyarakat

\section{Opportunities $(\mathrm{O})$}

1. Pelanggan loyal

2. Produk bisa digunakan untuk semua kalangan

3. Harga menengah kebawah

$$
\text { Strategi S-O }
$$

1. Meningkatkan penjualan dengan memanfaatkan kemajuan teknologi yang ada

2. Pelayanan yang memuaskan

3. Menambah variasi produk dalam daftar produk yang bisa dilayani
1. Kondisi finance terbatas

2. Promotion tidak efisien

3. Bentuk produk kurang bervariasi

4. Kualitas SDM yang terbatas

\section{Strategi W-O}

1. Mempromosikan produk melalui media online

2. Menjalin hubungan baik ke konsumen.

3. Mendaftarkan usaha pada komunitas sehingga akses dan jaringan pemasaran semakin luas

4. Memperbaiki program pelatihan untuk SDM

Threats (T)

1. Tingkat persaingan tinggi

2. Fluktuasi harga bahan baku

3. Permainan harga dari kompetitor

4. Kompetitor mulai meniru produk yang diproduksi

5. Tingkat Inflasi meningkat

\section{Strategi-ST}

1. Inovasi produk \& memberikan diskon

2. Memberikan pelayanan yang berkualitas dan cepat

3. Memperbaiki sumber daya manusia dan meningkatkan hubungan baik antara seluruh elemen di usaha tersebut.

\section{Strategi-WT}

1. Melakukan inovasi dan pengembangan produk dan pemasaran

2. Melakukan promosi secara maksimal dan menarik.

3. Menjaga stabilisasi baik bahan baku, pemasaran sampai tenaga kerja

Sumber : Data diolah (2021)

Berdasarkan Tabel 5, dari penggabungan faktor internal-eksternal usaha tersebut diperoleh suatu rekomendasi pemecahan masalah, yaitu sebagai berikut :

a. Strategi SO

Adapun kondisi ini merupakan sebuah hasil pemikiran dari pemilik UD. Abdi Rakyat dengan pemanfaatan kondisi kekuatan untuk mengambil pangsa pasar dan pemanfaatan peluang yang ada. Strategi SO yang dapat digunakan oleh UD. Abdi Rakyat yaitu strategi yang dapat meningkatkan penjualan dengan memanfaatkan teknologi yang ada yaitu Facebook, Instagram, Whatsapp maupun memberikan pelayanan yang memuaskan pada konsumen sehingga memberikan nilai lebih pada konsumen dan akan memberikan pengaruh terhadap citra UKM. Kemudian pada variasi produk seharusnya di tambah atau di ganti sehingga konsumen akan tertarik.

b. Strategi ST

Merupakan kondisi pemanfaatan kekuatan usaha UD. Abdi Rakyat untuk mengendalikan ancaman dari luar. Strategi ST yang dapat digunakan oleh UD. Abdi Rakyat yaitu melakukan inovasi pada produk yang diproduksi dan memberikan diskon pada konsumen sehingga ada kesan tersendiri. kemudian memberikan pelayanan yang berkualitas maupun cepat dengan semboyan pembeli adalah raja sehingga konsumen merasakan pelayanan yang puas. Serta memperbaiki sumber daya manusia meningkatkan hubungan baik antara seluruh elemen di usaha tersebut.

c. Strategi WO

Adapun kondisi ini menggunakan peluang di UD. Abdi Rakyat untuk meminimalkan kelemahan yang ada. Strategi WO yang dapat digunakan oleh UD. Abdi Rakyat dengan menjual produk melalui media online untuk mempromosikan sehingga pangsa penjualan semakin luas, menjalin hubungan baik dengan konsumen yang akan memberikan pengaruh baik pada usaha tersebut, meningkatkan modal yang dimiliki sehingga bisa mengembangkan usaha yang lebih besar lagi maupun mengembangkan produknya sehingga menarik banyak konsumen, mendaftarkan UD. Abdi Rakyat pada komunitas 
sehingga akses pemasaran semakin luas dan meningkatkan jaringan usaha. Memperbaiki kualitas SDM dengan mengikutkan pelatihan berbagai bidang yang sesuai.

d. Strategi WT

Adapun kondisi ini melakukan suatu hal untuk mengurangi kelemahan yang ada pada UD. Abdi Rakyat serta menyingkirkan ancaman dari luar. Strategi WT yang dapat digunakan oleh UD. Abdi Rakyat dengan melakukan inovasi dan pengembangan di bagian jenis produksi dan pemasaran sehingga konsumen tidak merasa bosan, melakukan promosi secara maksimal dan menarik yaitu dengan cara memberikan diskon pada konsumen yang membeli banyak produk, Menjaga stabilisasi baik bahan baku, pemasaran sampai tenaga kerja dengan cara ini usaha tersebut bisa terus eksis dan mampu bersaing lebih kompetitif dengan kompetitor lain.

\section{Diagram matriks SWOT}

Penggambaran diagram matriks SWOT bertujuan untuk menerangkan secara jelas kondisi peluang yang dimiliki oleh UD. Abdi Rakyat. Diagram matriks SWOT menghasilkan empat alternatif strategi, dimana nilai koordinat analisis internal diperoleh dengan melakukan pengurangan dari total nilai skor kekuatan dan kelemahan. Sedangkan untuk nilai koordinat analisis eksternal diperoleh dengan melakukan pengurangan dari total nilai skor peluang dan ancaman. Dari perhitungan dua koordinat yaitu internal dan eksternal, maka diperoleh 2 titik koordinat diagram matriks SWOT yaitu $(0,53 ; 0,10)$. Untuk penggambaran diagramnya ditunjukkan pada Gambar 3.

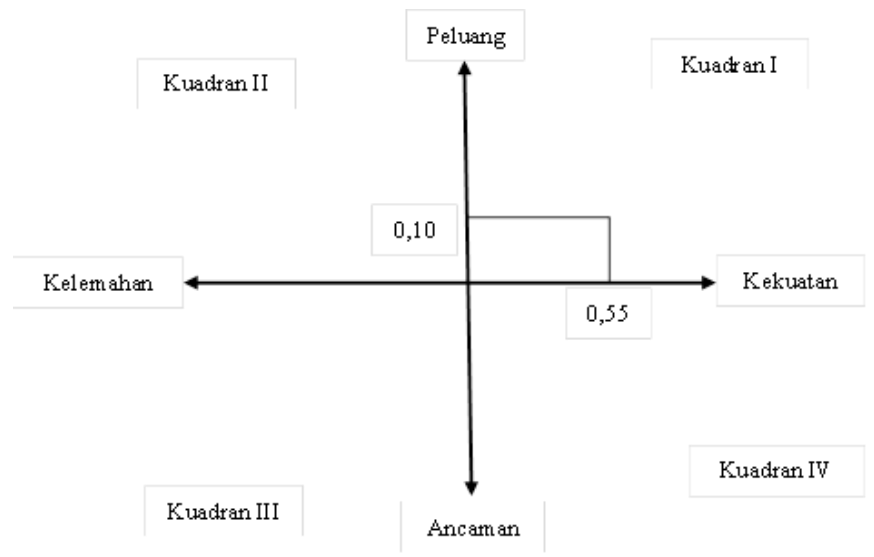

Gambar 2. Diagram matriks SWOT

Sumber : Data diolah (2021)

Gambar 2 menguraikan bahwa UD. Abdi Rakyat berada pada letak kuadran I, dikarenakan selisih nilai positifnya yaitu $(0,53 ; 0,10)$ atau dapat di indikasikan usaha tersebut dalam posisi tumbuh dan berkembang. Kondisi di kuadran I memiliki bobot nilai yang baik dalam faktor kekuatan dan faktor peluang. Sehingga disimpulkan bahwa UD. Abdi Rakyat dapat menggunakan strategi Growth Oriented Strategy yakni penggunaan strategi yang menguntungkan karena berada pada kondisi kekuatan yang baik untuk pemanfaatan peluang dari usaha tersebut.

\section{Matriks IE}

Matriks IE merupakan suatu penggambaran kondisi berbagai faktor internal-eksternal perusahaan yang untuk mendapatkan strategi bisnis yang sesuai. Adapun hasil penggambaran matriks IE ditunjukkan pada Tabel 6.

Tabel 6. Matriks IE

\begin{tabular}{|c|c|c|c|c|}
\hline \multirow{5}{*}{$\begin{array}{l}\text { EFAS } \\
\text { Score }\end{array}$} & \multicolumn{4}{|c|}{ IFAS Score } \\
\hline & & Kuat & Rata-Rata & Lemah \\
\hline & Tinggi & I & II & III \\
\hline & Sedang & IV & V & VI \\
\hline & Rendah & VII & VIII & IX \\
\hline
\end{tabular}

Sumber: Data diolah (2021)

Data analisis matriks IE Tabel 6 menjelaskan bahwa UD. Abdi Rakyat berada pada sel I, artinya perusahaan tersebut diindikasikan sebagai usaha grow dan build, sehingga usaha tersebut disarankan 
menggunakan strategi intensif dalam melakukan penetrasi pasar, pengembangan pasar dan pengembangan produk) dan integrasi (integrasi ke depan, integrasi ke belakang dan integrasi horizontal).

\section{Kesimpulan}

Metode analisis SWOT mengidentifikasi faktor internal-eksternal yang bertujuan untuk membuat strategi suatu perusahaan. Hasil analisis metode SWOT dalam penelitian ini, dapat ditarik 4 kesimpulan, pertama penggambaran matriks IFAS menyatakan bahwa faktor kekuatan memiliki nilai skor 2,86 sedangkan kelemahan memiliki nilai skor 2,33. Dan untuk matriks EFAS menyatakan bahwa faktor peluang memiliki nilai skor 1,80, sedangkan untuk ancaman memiliki nilai skor 1,70. Kedua hasil dari penggambaran diagram matriks SWOT menunjukkan bahwa UD. Abdi Rakyat berada pada kondisi kuadran I, dikarenakan selisih nilainya positif dan memiliki bobot nilai yang baik dalam faktor kekuatan dan faktor peluang. Ketiga, hasil dari analisis matriks IE menunjukkan hasil bahwa UD. Abdi Rakyat berada pada sel I, artinya kondisi perusahaan dinilai sebagai grow dan build.

Keempat, dari berbagai banyak macam pembentukan strategi peningkatan penjualan produk lemari di UD Abdi rakyat, maka disimpulkan bahwa usaha tersebut perlu mengaplikasikan strategi SO agar tujuan perusahaan dapat tercapai dengan cepat dan tepat. Dengan melihat kekuatan yang dimiliki maka dapat dipastikan usaha tersebut dapat lebih berkembang dan sukses daripada kompetitornya. Adapun untuk kondisi kelemahan yang dimiliki harus segera dilakukan perbaikan agar usaha tersebut bisa tetap eksis dan menerima banyak orderan. Peluang yang ada harus segera dimanfaatkan dengan baik agar jumlah penjualan meningkat dan ancaman terhadap usaha tersebut juga harus dicapai dengan pengembangan strategi pemasaran yang baik.

\section{Saran}

Terdapat saran kepada UD. Abdi Rakyat sebagai pertimbangan yang mengarah, sebagai berikut : perlu adanya pengembangan SDM dengan pembekalan, pelatihan, pendidikan, motivasi yang bertahap, berjenjang, berkesinambungan dan berkelanjutan. Pembacaan situasi mengenai pasar sangatlah penting untuk menentukan strategi pemasaran yang lebih tepat.

\section{Referensi}

[1] M. Anggrianto, C. I. Parwati, And S. Sidharta, "Penerapan metode SWOT dan BCG guna menentukan strategi penjualan," J. Rekavasi, Vol. 1, No. 1, Pp. 28-35, 2013.

[2] Y. Sinambela, Darnianti, dan N. Panjaitan, "Analisis startegi pemasaran CV Karunia Makmur Persada (KMP) dengan metode Swot,” J. Juitech, Vol. 2, No. 2, pp. 56-66, 2018.

[3] T. Mulyana dan R. Firdaus, "Analisis strategi pemasaran PT. Vivo Communication Indonesia Area Garut dengan metode Swot dan matriks BCG,” J. Wacana Ekon., Vol. 17, No. 01, pp. 052-062, 2017.

[4] E. Zuraidah, "Analisis strategi pemasaran sparepart kendaraan menggunakan metode Swot," $J$. Prosisko, Vol. 7, No. 1, pp. 54-65, 2020.

[5] P. Cahyono, "Implementasi strategi pemasaran dengan menggunakan metode swot dalam upaya meningkatkan penjualan produk jasa asuransi kecelakaan dan kematian pada PT. Prudential Cabang Lamongan," J. Penelit. Ilmu Manaj., Vol. 1, No. 2, Pp. 129-138, 2016.

[6] M. K. Mutakin dAn N. Safa'atillah, "Analisis strategi pemasaran metode swot dalam upaya meningkatkan penjualan pada PT. Aj Central Asia Raya Cabang Surabaya," J. Media Mahard., Vol. 17, No. 1, pp. 103-109, 2018.

[7] A. A. Mokoginta, L. Mananeke, dan R. J. Jorie, "Implementasi strategi pemasaran dengan menggunakan metode swot dalam upaya meningkatkan penjualan produk asuransi tabungan pada PT. Prudential Cabang Manado," J. EMBA, Vol. 7, No. 3, pp. 4349-4357, 2019.

[8] M. Samsudin dan M. Waluyo, "Analisis strategi promosi produk kopi tarik untuk meningkatkan volume penjualan pada divisi promosi dengan metode Swot dan Bcg di PT. XYZ," Juminten J. Manaj. Ind. dan Teknol., Vol. 2, No. 2, pp. 144-155, 2021, Doi: 10.33005/Juminten.V2i2.131.

[9] H. Bahari, E. Leksono, dan E. Ismiyah, "Pendekatan risk management \& analisis swot untuk mengantisipasi penurunan laba di Ecos Minimart Gresik," J. Matrik, Vol. 18, No. 2, Pp. 23-40, 2018, Doi: $10.350587 /$ Matrik.

[10] A. Pratama, W. Tambunan, dan F. D. Sitania, "Analisis strategi pemasaran jasa percetakan dengan menggunakan metode swot dan analytic hierarchy process," J. Ind. Manuf. Eng., Vol. 4, No. 1, pp. 12-21, 2020, Doi: 10.31289/Jime.V4i1.2972.

[11] A. Qanita, "Analisis strategi dengan metode swot dan qspm (quantitative strategic planning matrix): 
studi kasus pada d'gruz caffe di Kecamatan Bluto Sumenep," Komitmen J. Ilm. Manaj., Vol. 1, No. 2, pp. 11-24, 2020, Doi: 10.15575/Jim.V1i2.10309.

[12] M. A. Bora dan S. Machfudzi, "Analisa strategi pemasaran penjualan martabak menggunakan metode swot," J. Tek. Ibnu Sina, Vol. 5, No. 2, Pp. 25-35, 2020, Doi: 10.3652/Jt-Ibsi.V5i02.249.

[13] M. N. Sijabat, F. Sains, D. A. N. Teknologi, U. Islam, N. Sultan, dan S. Kasim, "Analisis strategi pemasaran dengan menggunakan metode swot dan ahp untuk meningkatkan volume penjualan (studi kasus: toko roti ayah bakery)," Semin. Nas. Teknol. Informasi, Komun. Dan Ind. 11, No. November, Pp. 609-616, 2019.

[14] L. Herawati, D. Gustopo, And P. Vitasari, "Identifikasi permasalahan penjualan dengan metode swot pada ukm gula merah,” J. Teknol. Dan Manaj. Ind., Vol. 6, No. 1, Pp. 17-20, 2020, Doi: 10.36040/Jtmi.V6i1.2625.

[15] R. T. Arisman, "Implementasi strategi pemasaran dengan menggunakan metode swot dalam upaya meningkatkan penjualan produk perkayuan narapidana di lapas kelas IIa Lahat1," Nusant. J. Ilmu Pengetah. Sos., Vol. 8, No. 4, Pp. 474-488, 2021.

[16] D. Mulyati, K. Khairiadi, S. Yana, dan I. Zein, "Pengembangan potensi wisata di Kota Banda Aceh dengan analisa SWOT,” J. Serambi Eng., Vol. 3, No. 1, pp. 292-298, 2018, [Online]. Available: Http://www.Jurnal.Serambimekkah.Ac.Id/Jse/Article/View/440. 